\title{
Electrophoretic Study of Seed Storage Protein in Five Species of Bauhinia
}

\author{
Kumari Nutan Sinha ${ }^{1}$ Meenakshi Singh ${ }^{2}$ And Chandan Kumar ${ }^{3}$ \\ Plant Biodiversity and Molecular Biology Lab., \\ Patna Science College, Patna University, Patna
}

\begin{abstract}
Seed storage Protein profiles of five Bauhinia species were analysed by sodium dodecyl sulphate polyacrylamide gel electrophoresis (SDS-PAGE). Total seed storage protein of Bauhinia species resolved on $10 \%$ SDS Polyarylamide gels showed variations in their banding pattern. Results of SDS-PAGE pattern of a few protein bands were up regulated whereas some other bands showed down regulation. Beside the common bands among the studied taxa, $7.37 \mathrm{kDa}, 31.85 \mathrm{kDa}$ and $261.143 \mathrm{kDa}$ protein were found common in all the species. The maximum genetic affinities has been observed between $B$. acuminata $x$ B. purpurea, while minimum between B. racemosa and B. variegata. On the molecular level, present study gave the results with wide variations in their band numbers. Maximum number of protein bands (12 bands) were observed in $B$. tomentosa, while minimum ( 7 bands) in B. purpurea and B. variegata. From present results, protein can differentiate between the studied Bauhinia species by producing some specific bands that could be used to distinguish any species from each other. It could be concluded that SDS-Protein is important for genetic analysis and indicate a considerable amount of genetic diversity between the different studied Bauhinia species.
\end{abstract}

Keywords: Bauhinia species, SDS-PAGE, Storage protein, Genetic affinity, Electrophoresis

\section{Introduction:}

The seed storage protein analysis helps in identification and characterization of diversity in crop varieties, cultivars and their wild varieties and also provides information on phylogenetic relationship of the accession $[1,2,3]$. Since many species are genetically closely related, it is often difficult to morphologically discriminate differences among species. Currently, biochemical methods especially SDS-PAGE is widely used in studies on phenotypically close taxa because SDS-PAGE of seed protein is a simple and effective method which is used as genetic markers in the study of genetic variation.

Electrophoresis of protein is a powerful tool for identification of genetic diversity and the SDS-PAGE is particularly considered as a reliable technology because seed storage proteins are highly independent of environmental fluctuations $[4,5]$. Seed protein patterns can also be used as a promising tool for distinguishing cultivars of particular crop species [6,7]. The SDS-PAGE is considered to be a practical and reliable method for species identification $[8]$

Since in mature seeds, type and amount of proteins are more constant than other plant tissues [9] therefore, the SDS-PAGE pattern of seed storage proteins of selected species showed polymorphism on the basis of difference in protein intensity among genotypes. The present investigation revealed variation in selected species with regard to their total seed storage protein profiles.

During the present investigation, five taxa viz. Bauhinia acuminata L., Bauhinia purpurea L., Bauhinia racemosa Lam., Bauhinia tomentosa L., Bauhinia variegata L., of the genus Bauhinia have been selected.Bauhinia Linn. is a genus with more than 300 species, of family Caesalpiniaceae. It is the largest genus in the legume tribe Cercideae, sub tribe Bauhiniiae [10,11]. Bauhinia genus consisting of trees, climbers and shrubs is distributed in India [12]. It has great medicinal value.

\section{Materials and Methods}

1.1 Plant Material: Fresh mature seeds of selected species of Bauhinia were collected from different localities of Patna.

1.2 Protein Extraction: Protein was extraceted by method given by Jensen and Lixue [13]. Protein was extracted from overnight presoaked seeds in protein solubilization solution $(62 \mathrm{~m} \mathrm{M}$ Tris $-\mathrm{HCl}, \mathrm{pH} 6.8$, $10 \%$ glycerol, $2 \%$ SDS, p- mercaptoethanol and traces of bromophenol blue) then transferred to Eppendorf tube and centrifuged at $14000 \mathrm{rpm}$ for 30 seconds. The supernatent was transferred to a fresh tube and placed into a boiling water bath for 4 minutes.

1.3 SDS-PAGE: SDS-PAGE was done by method suggested by Laemmli [14]. It was performed on a vertical slab gel. Bromophenol blue was added to the supernatant as tracking dye to watch the movement of protein in 
the gel. Seed protein was analyzed through slab type SDS-PAGE using 10\% Separating gel and 4\% Stacking gel.

Molecular weight of different bands were calibrated with a mixture of standard protein markers include Myosin (261.143 kDa), Phosphorylase B (137.190kDa), BSA (102.564 kDa), Ovalbumin (54.854 kDa), Carbonic Anhydrase (37.670 kDa), Lysozyme (orange) (31.854 kDa), Lysozyme (21.769 kDa) and Aprotinin $(7.337 \mathrm{kDa})$.

Protein Electrode buffer solution was poured into the bottom pool of the apparatus. Gel plates were placed in the apparatus carefully so as to prevent bubbles formation at the bottom of gel plated. Equal quantity of extracted protein from each sample along with Protein molecular weight marker (PAGE mark) were loaded with the micropipette into each wells of the gel. The apparatus was connected with constant electric supply. Electrophoresis was carried out at $20 \mathrm{~mA}$ current for 3-4 hours till the tracking dye reaches the bottom of the gel. After electrophoresis, the protein bands were visualized by staining with coomassie brilliant blue G-250 and destained with methanol, acetic acid and water (4:1:5).

1.3.1 Gel Documentation and Analysis: Finally gel was photographed. Molecular weight of protein bands were estimated by their relative mobality.

Pairing affinity or Similarity index was calculated by the method described by the formula.

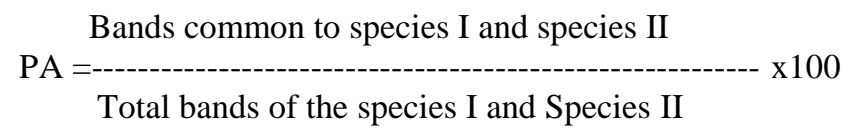

\section{Result and Discussion}

Seed storage protein was analyzed through SDS-PAGE using 10\% Polyacrylamide gel. The pattern of the total protein content in five species of Bauhinia showed some variation among them. The Rf value between different species ranged from 0.08 to 0.91 (Table-1). The value depect the mobility of the protein on gel surface. Polymorphism was observed in three variable regions i.e. high, medium and low molecular weight. Molecular weight of proteins ranged from $7.37 \mathrm{kDa}$ to $261.143 \mathrm{kDa}$ ). Band $1(\mathrm{Rf}=0.08$, mol. wt. $261.143 \mathrm{kDa})$ and band $22(\mathrm{Rf}=0.90$, mol.wt. $7.37 \mathrm{kDa})$ was exactly alike in all the species.

The SDS banding pattern of protein produced 22 bands distributed in all the species including marker with mol. wt. $7.337 \mathrm{kDa}$ to $261.143 \mathrm{kDa}$ (Fig.1-2). Maximum number of protein bands (12 bands) were observed in B. tomentosa, while minimum (7 bands) in B. purpurea and B. variegata. Beside the common bands among the studied taxa, $7.37 \mathrm{kDa}, 31.85 \mathrm{kDa}$ and $261.143 \mathrm{kDa}$ protein were found common in all the species. $7.337 \mathrm{kDa}, 31.85 \mathrm{kDa}, 49.95 \mathrm{kDa}, 89.74 \mathrm{kDa} 148.622 \mathrm{kDa}, 254.77 \mathrm{kDa}$ and $261.143 \mathrm{kDa}$, proteins were found in $B$. racemosa and $B$. tomentosa while $7.337 \mathrm{kDa}, 31.85 \mathrm{kDa}, 41.56 \mathrm{kDa}, 54.854 \mathrm{kDa}$ and $261.143 \mathrm{kDa}$ proteins were found to be common in $B$. acuminata and B. purpurea. The pairing affinity index calculated on the basis of electrophoric patterns of seed protein. The percentage similarities for five species belonging to genus Bauhinia ranged from $20 \%$ to $45.45 \%$ (Table-2). Maximum amount of pairing affinity was observed between the two species viz. B. acuminata and B. purpurea $(45.45 \%)$ while minimum affinity was observed between $B$. racemosa and $B$. variegata (20\%).

According to the result of SDS-PAGE, the overall pattern of seed - storage protein showed the diversity of Bauhinia species. The diversity in seed storage protein has also been reported by Khan et al.,[15] for wheat varieties.

Collectively, seed storage protein profiling using SDS-PAGE has the potential to make a distribution between species. Clustering based on seed storage protein profile provides information about the phylogenetic relationship.

\section{Conclusion}

Five Bauhinia species were used in order to elucidate their genetic diversity by using SDS-proteins. It could be concluded that the present results, protein can differentiate between the studied Bauhinia species by producing some specific bands that could be used to distinguish any species from each others. These species variation were analysed to assess the protein polymorphism between different species of Bauhinia.

On the molecular level, present study gave the results with wide variations in their band numbers. It could be concluded that SDS-Protein is important for genetic analysis and indicate a considerable amount of genetic diversity between the different studied species of Bauhinia. 


\section{Reference}

[1] Nisar, M. A Ghafoor, M.R. Khan, H. Ahmad, A.S. Qureshi \& H. Ali Genetic diversity and geographic relationship among local \& exotic chickpea germplasm. Park. J. Bot. 39, 2007, 1575-1581.

[2] Tanksley. S.D and Jones R.A. Application of alcohol dehydrogenase allozymes in testing the genetic purity of $F_{1}$ hybrid of tomato. Hort. Sci., 16, 1981, 179-1871.

[3] Thanh V.O.C and Hirata Y. Seed storage protein diversity of three rice species in the Mekong Datta. Biosphere conservation 4, 2002, 59-67.

[4] Javid, A., A. Ghafoor and R. Anwar. Seed Storage Protein electrophoresis in ground nut for evaluating genetic diversity. Pak. J. Bot., 36, 2004, 87-96.

[5] Iqbal, S.H.,Ghafoor A. and Ayub, N. Relationship between SDS-PAGE markers and Ascochyta blight in chickpea, Pakistan Journal of Botany, 37 (1), 2005, 87-96.

[6] Jha, S.S. and Ohri, D. Phylogenetic relationships of Cajanus cajan (L.) Millsp. (pigeonpea) and its wild relatives based on seed protein profiles. Genetic Resources and Crop Evolution, 43(3), 1996. 275-281.

[7] Seferoglua, S., Seferoglua, H.G., Tekintasa, F.E and Baltab, F. Biochemical composition influenced by different location in Uzun pistachio CV. (Pistacia vera L.) grown in Turkey Journal of food Composition and Analysis 19 (5), 2006. 461-465.

[8] Gepts, P. Genetic diversity of seed storage proteins in plants. In: Brown, A. H. D., Clegg, M. T., Kahler, A. L. and Weir, B. S., Eds., 1989. Plant Population.

[9] Magni C., Scarafoni, A., Herndl, A., Sesse F., Prinsi, B., Espen, L. and Duranti, M. Combined 2D electrophoretic approaches for the study of white Lupin mature seed storage protein Phytochemistry, 68(7), 2007, 997-1007.

[10] Bruneau A., Forest F., Herendeen P. S., Kligaard B. B. and Lewis G. P. Phylogenetics relationship in the Caesalpinioideae (Leguminosae) as inferred from Chloroplast trnL. Intron Sequences. Systematic Botany, 26 (3), 2001 : 487-514.

[11] Kajita, T., H. Ohashi, Y. Tateishi, C. D. Bailey, and J. J. Doyle, rbcL. and Legume phylogeny, with particular reference to Phaseoleae, Millettieae, and allies. Systematics Botany 26, 2001, 515 - 536.

[12] Valdir C. Chemical Composition and Biological potential of plants from the genus Bauhinia. Phytother Res 23, 2009, 134754.

[13] Jansen U., Lixue C.. Abies seed protein profile divergent from other Pinaceae Taxon, 40, 1991, 435-440.

[14] Laemmli, U.K. Cleavage of structural proteins during the assembly of the head of bacteriophage $T_{4}$. Nature, 227, 1970, 680-685

[15] Khan, M.F., Schumann, E. and Weber, E.E. Characterization of Pakistani wheat varieties for general cultivation in the mountainous regions of Azad Kashmir. Asian Journal of Plant Science, 1(6), 2002. 699-702.

TABLE - 1

The Rf value of the various bands that appeared on gel of Bauhinia species

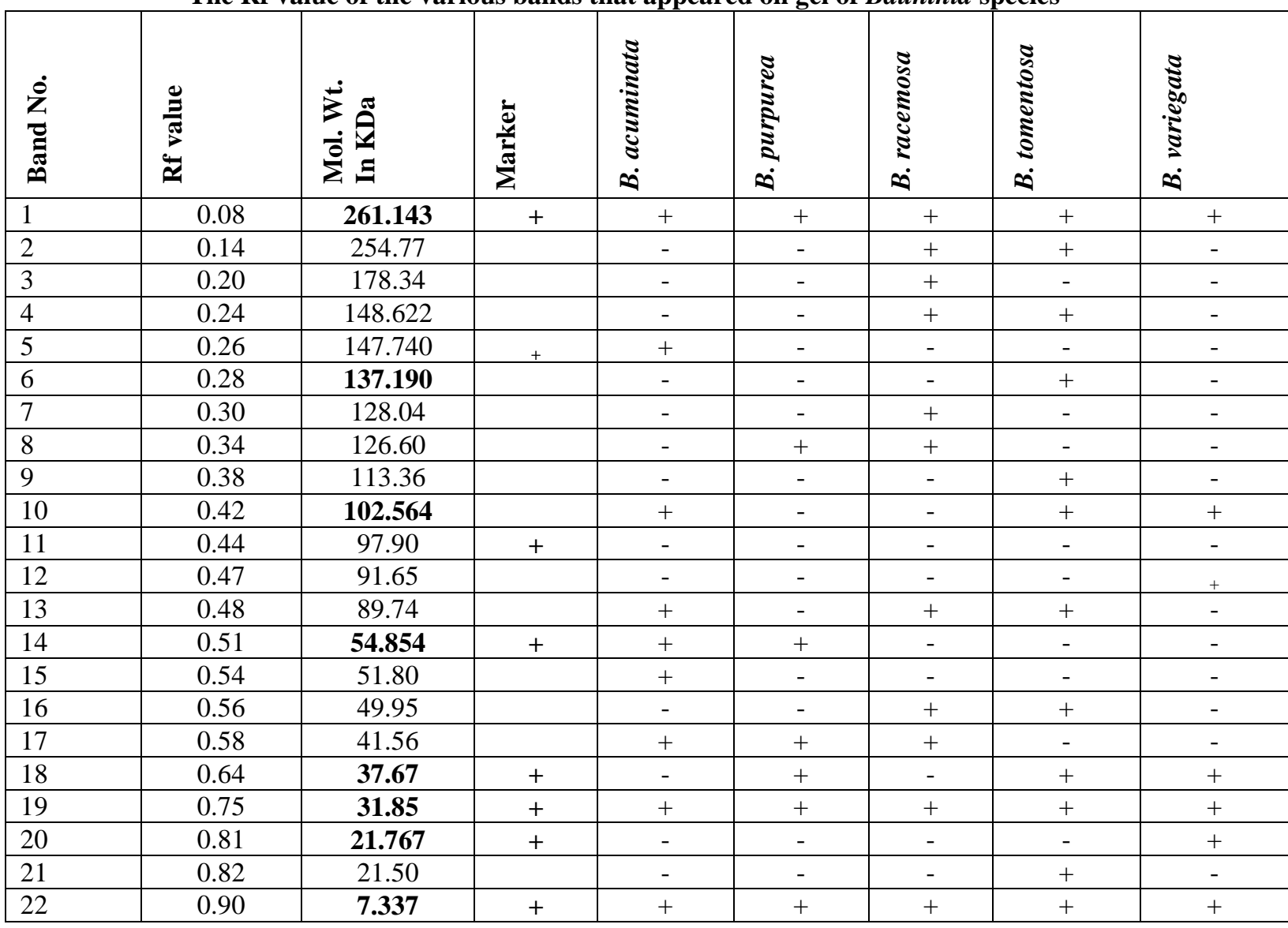


TABLE- 2

Percentage Similarity Index between Bauhinia Species

\begin{tabular}{|c|c|c|}
\hline S. No. & Species $\mathrm{x}$ Species & Percentage Similarity \\
\hline 1 & B. acuminata $\times$ B. purpurea & $45.45 \%$ \\
\hline 2 & B. acuminata $\times$ B. racemosa & $33.33 \%$ \\
\hline 3 & B. acuminata $\times$ B.tomentosa & $31.25 \%$ \\
\hline 4 & B. acuminata $\times$ B. variegata & $33.33 \%$ \\
\hline 5 & B.purpurea $\mathrm{x}$ B. racemosa & $38.46 \%$ \\
\hline 6 & B. purpurea $\mathrm{x} \quad$ B. tomentosa & $26.66 \%$ \\
\hline 7 & B. purpurea $\quad \mathbf{X} \quad$ B. variegata & $40.00 \%$ \\
\hline 8 & B. racemosa $\times$ B.tomentosa & $43.75 \%$ \\
\hline 9 & B. racemosa $\mathrm{x}$ B. variegata & $20.00 \%$ \\
\hline 10 & B. tomentosa $\times$ B. variegata & $35.71 \%$ \\
\hline
\end{tabular}

Fig. 1. SDS Protein profiles of $[\mathrm{A}]$ B. variegata $[\mathrm{M}]$ Marker $[\mathrm{B}]$ B. acuminat $[\mathrm{C}]$ B. purpurea $[\mathrm{D}]$ B. racemosa $[\mathrm{E}]$ B. tomentosa

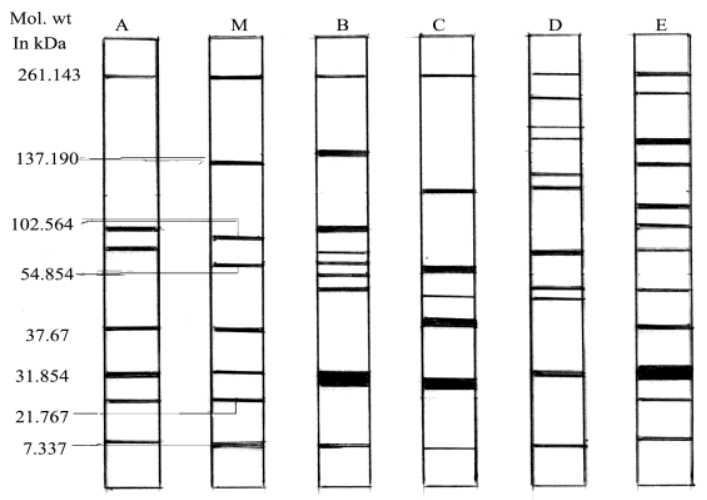

Fig. 2. Diagramatic representation of SDS Protein profile of seed of $[\mathrm{A}]$ B. variegata [M] Marker; [B] B. acuminata; $[\mathrm{C}]$ B. purpurea; $[\mathrm{D}]$ B. racemosa; $[\mathrm{E}]$ B. tomentosa 